Prace Literackie LVIII

Wrocław 2018

https://doi.org/10.19195/0079-4767.58.22

DOROTA UCHEREK

ORCID: 0000-0001-6794-7280

Uniwersytet Wrocławski

\title{
Baba Jaga, Kościej Nieśmiertelny i inne postacie władające magią w rosyjskich baśniach magicznych a wiedźmy i czarownicy Grimmowscy
}

Omówione już szeroko obrazy postaci władających magią pojawiające się w baśniach braci Grimmów ${ }^{1}$ warto zestawić z tymi charakterystycznymi dla innego europejskiego kręgu kulturowego: wschodniosłowiańskiego. Reprezentatywnym dla tego kręgu zestawem ludowych opowieści interesującego nas typu jest tom przygotowany przez rosyjskiego filologa, etnografa i folklorystę - Aleksandra Afanasjewa. Zbiór, ukazujący się w kolejnych zeszytach serii w latach 18551864, obejmuje 640 tekstów i można powiedzieć, że

utrwalił się w powszechnej świadomości i Rosjan, i cudzoziemców jako pomnikowe wydanie bajek, jako zabytek narodowego piśmiennictwa o randze dzieła klasycznego [...] z racji zarówno bogactwa i kompletności przekazów [...], jak i ze względu na aspekt naukowy, systematyzacyjno-normatywny tego przedsięwzięcia².

Z punktu widzenia niniejszej pracy najbardziej interesującą grupą tekstów ze zbioru Afanasjewa będą - podobnie jak w wypadku tomów Grimmowskich — opowieści o charakterze fantastycznym, nazywane zwykle baśniami właściwymi. Tworzą one główną część kolekcji rosyjskiego folklorysty. Należą do drugiej grupy wyodrębnionej przez Antii Aarnego i Stitha Thompsona (obok legend religijnych i tak zwanych bajek-nowel, przedstawiających niecodzienne przygody) ${ }^{3}$

${ }^{1}$ Zob. D. Ucherek, Sposoby funkcjonowania postaci czarownic i czarowników oraz magicznych przedmiotów w baśniach braci Grimmów, „Literatura Ludowa” 2015, nr 4/5.

${ }^{2}$ R. Łużny, Aleksander Afanasjew i jego „,Rosyjskie bajki ludowe”, [w:] Rosyjskie bajki ludowe ze zbioru Aleksandra Afanasjewa, oprac., wstęp, przypisy R. Łużny, wyb., przygot. do druku H. Kowalska, Kraków 2001, s. 19.

${ }^{3}$ Chodzi o systematykę zaproponowaną przez fińskiego folklorystę Antii Aarnego w pracy Verzeichnis der Märchentypen (Helsinki 1910), udoskonaloną przez amerykańskiego uczonego Stitha Thompsona w reedycji rozprawy The Types of the Folk-Tale. A Classification and Bibliography 
i w nich właśnie najczęściej pojawiają się postacie interesującego nas rodzaju. W rosyjskich baśniach są to przede wszystkim czarownice, ale też czarownicy, smoki oraz niezwykłe zwierzęta.

Do analizy wymienionych elementów rosyjskiej prozy baśniowej posłuży najobszerniejsze, jak dotąd, polskie wydanie tekstów zgromadzonych przez Afanasjewa. Wydanie to ukazało się w ramach redagowanej przez Lucjana Suchanka serii „Prace Komisji Kultury Słowian” Polskiej Akademii Umiejętności. Jest tłumaczeniem zbiorowym, nad którym czuwał wybitny polski uczony Ryszard Łużny - filolog rosyjski, badacz literatury, historii i kultury wschodniosłowiańskiej. Pięcioosobowy zespół (obok Łużnego także Aleksander Barszczewski, Małgorzata Biernacka, Hanna Kowalska i Anna Woźniak) przełożył około połowy tekstów ze zbioru Afanasjewa, ale ostatecznie do druku przygotowano 150 tytułów, czyli ćwierć tegoż zbioru. Wybór ów można jednak uznać za wyczerpujący w kontekście niniejszej pracy, gdyż tom zawiera najistotniejsze, reprezentatywne dla całości kolekcji tytuły (przykłady każdego z typów bajek wyodrębnionych przez Aarnego i Thompsona), ułożone zgodnie z zamysłem Afanasjewa. Baśnie właściwe - to jest stosunkowo obszerne utwory nowelistyczno-fantastyczne - zajmują w nim, tak jak w rosyjskim oryginale, miejsce „szczególnie eksponowane”, jako „najbardziej atrakcyjne”, bo pozwalające na „zobiektywizowanie się w akcie twórczym właściwej człowiekowi tendencji do wychodzenia poza [...] przyziemność i przeciętność, [...] rekompensowania codzienności i materialności [wizją] świata idealnego, bardziej sprawiedliwego, mądrzejszego i lepszego [...] niż ten, jaki twórcę i słuchacza otaczał"4.

\section{Wieloznaczna Baba Jaga}

Najbardziej znaną bohaterką władającą magią, jaka wywodzi się z ludowych wierzeń i twórczości pochodzących z terenów, na których skupiamy uwagę w tym artykule, jest Baba Jaga. Andreas Johns, autor monografii na jej temat, nazywa ją jedną z najmocniej zapadających w pamięć i charakterystycznych postaci nie tylko z rosyjskiego, lecz także całego wschodnioeuropejskiego czy wschodniosłowiańskiego folkloru. Wskazuje, że narratorzy baśni zwykle identyfikują ją z czarownicami, ale tak naprawdę jej pochodzenie i status są niejasne: Baba Jaga może

(Helsinki 1961), a następnie zrewidowaną i rozwiniętą przez niemieckiego folklorystę i literaturoznawcę Hansa-Jörga Uthera w obszernej, trzytomowej publikacji The Types of International Folktales: A Classification and Bibliography, Based on the System of Antti Aarne and Stith Thompson (Helsinki 2004).

${ }^{4}$ R. Łużny, op. cit., s. 20-21. Rosyjskojęzyczny stan badań nad bajką magiczną z tego obszaru zob. I. Rzepnikowska, Rosyjska i polska bajka magiczna (AT 480) w kontekście kultury ludowej, Toruń 2005, s. 252-260. 
być zarówno po prostu wiedźmą, jak i demonem, a nawet bóstwem. Samo zaś słowo „wiedźma” na pewno nie wyczerpuje „złożoności i bogactwa” tej postaci ${ }^{5}$.

Podobnie jak stereotypowa czarownica Baba Jaga mieszka w lesie, ale jej pozostałe atrybuty są absolutnie wyjątkowe. Jack Zipes w tytule swojej przedmowy do amerykańskiego wyboru rosyjskich baśni na jej temat nazywa ją ,niezgłębioną", a w samej przedmowie podkreśla, że ,żadna inna wiedźma / mądra niewiasta nie jest tak szeroko opisana i obdarzona tak niezwykłym »oprzyrządowaniem «"6. Analiza baśni ze zbioru Afanasjewa, w których pojawia się ta bohaterka, powinna zweryfikować owe twierdzenia.

Najbardziej znaną rosyjską baśnią magiczną, w której występuje postać Baby Jagi, jest Piękna Wasylisa (nr $104 \mathrm{w}$ zbiorze Afanasjewa, $31 \mathrm{w}$ polskiej edycji), swoista realizacja wątku opowieści o Kopciuszku. O interesującej nas postaci, która mieszka w chatce stojącej, oczywiście, w „ciemnym lesie”, mówi się, że nie znosi intruzów, nikogo nie wpuszcza i zjada ludzi ,jak kurczęta”7. Opis domostwa skonstruowany jest tak, by jak najskuteczniej budzić w słuchaczu grozę: „Płot wokół niej [to jest chaty Baby Jagi] był z ludzkich piszczeli, na płocie sterczały trupie czaszki z oczami; zamiast palików u wrót - ludzkie nogi, zamiast skobli — ręce, zamiast zamka - usta z ostrymi zębami”"8. Po nastaniu zaś nocy oczodoły czaszek rozbłyskują jasnym, oślepiającym światłem.

Najbardziej wyją̧tkowy odnośnie do opisywanej postaci, tak charakterystycznej dla rosyjskiego folkloru, jest sposób, w jaki się ona przemieszcza: „na stępie, tłuczkiem pogania, miotłą ślady zamiata"9. Inaczej niż zachodnia czarownica, latająca zazwyczaj na miotle, Baba Jaga porusza się w ,przyrządzie do [...] obtłukiwania lub miażdżenia ziarna" ${ }^{10}$, za swoiste wiosło służy jej tłuczek (dawniej

${ }^{5}$ A. Johns, Baba Yaga: The Ambiguous Mother and Witch of the Russian Folktale, New York 2006, s. 2.

${ }^{6}$ J. Zipes, Unfathomable Baba Yagas, [w:] Baba Yaga: The Wild Witch of the East in Russian Fairy Tales, wstęp i przekł. S. Forrester, Jackson, MS, 2013, s. xi.

${ }^{7}$ Rosyjskie bajki ludowe..., s. 77, 78.

${ }^{8}$ Ibidem, s. 78. Jeszcze bardziej szczegółowy — i budzący większą grozę — opis domu Baby Jagi znajdujemy w wersji Pięknej Wasylisy przytaczanej przez C.P. Estés (Biegnaca z wilkami, przeł. A. Cioch, Poznań 2001, s. 105): „niesamowity był [...]. Stał na ogromnych, pokrytych łuskami, żółtych kurzych nogach i wędrował tu i tam, a czasem wirował w kółko jak ekstatyczny tancerz. Rygle na drzwiach i okiennicach zrobione były z ludzkich palców rąk i nóg, a zamek u drzwi frontowych był pyskiem, z którego wystawało mnóstwo ostrych kłów".

${ }^{9}$ Rosyjskie bajki ludowe..., s. 78. W wersji C.P. Estés (op. cit., s. 105) Baba Jaga zamiata ślady „miotłą zrobioną z włosów zmarłych”.

${ }^{10}$ W. Doroszewski, Stępa, [hasło w:] idem, Wielki słownik języka polskiego, http://sjp.pwn.pl/ doroszewski/stepa;5501106.html [dostęp: 9.01.2017]. W wielu przekazach środek lokomocji Baby Jagi jest nazywany moździerzem — błędnie, gdyż słowo to oznacza o wiele mniejsze od stępy naczynie kuchenne, „służące do ucierania na miałki proszek cukru, wanilii, pieprzu itp.”, a ponadto określa cały ów przyrząd, czyli i miseczkę, i thuczek (idem, Moździerz, [hasło w:] idem, Wielki stownik..., http://sjp.pwn.pl/doroszewski/mozdzierz;5453222.html [dostęp: 9.01.2017]). W wariancie przywoływanym przez C.P. Estés (op. cit., s. 105) jest to „kocioł w kształcie moździerza”, a informacja o nim staje się punktem wyjścia do bogatego w detale opisu wyglądu samej Baby Jagi: 
zwany stęporem), a „zachodni” środek lokomocji ma tylko uniemożliwiać wyśledzenie tajemniczej istoty. Podkreśla to proweniencję postaci Baby Jagi — jej wywodzenie się z kultury agrarnej.

Kolejnym charakterystycznym zachowaniem Baby Jagi jest węszenie dookoła. Wyczuwając obecność Wasylisy, mieszkanka chatki stwierdza: „Pachnie tu człowiekiem" "11, co może wskazywać, iż ona sama bynajmniej nie należy do gatunku ludzkiego. Podobna reakcja była przecież typowa dla gryfa z Grimmowskiej baśni 165, w którego wypadku niehumanoidalny status wydaje się jasny. Analogicznie wolno dopatrywać się w Babie Jadze nie kobiety obdarzonej nadnaturalnymi mocami, lecz bytu zupełnie odmiennego niż człowiek.

Wbrew obiegowym przekonaniom Baba Jaga nie zjada Wasylisy zaraz po jej dostrzeżeniu. Wręcz przeciwnie: zgadza się, żeby ogień, którego potrzeba w domu dziewczyny, był zapłatą za jej pracę. Wypełniając nader prozaiczne zadania, Wasylisa ma okazję zauważyć, jak zasobna jest chatka Baby Jagi — niczego tam nie brakuje. Motyw służby u niezwykłej postaci, będącej swoistą próbą, często pojawia się w baśniach różnych kręgów kulturowych. Jest charakterystyczny na przykład dla opowieści o pani Holle ze zbioru Grimmów ${ }^{12}$. Postać pani Holle bywa zresztą niekiedy utożsamiana z rosyjską Babą Jagą ${ }^{13}$. Jednak najpierw Wasylisa podaje „gospodyni” kolację: tajemnicza istota przyjmuje taką ilość pożywienia, jaką nasiciłoby się 10 zwykłych osób, a do tego nie mniejszą objętość rozmaitych trunków: kwasu, miodu, piwa i wina. Te elementy podkreślają znowu jej nieludzki status ontologiczny.

Baba Jaga niewątpliwie jest postacią władającą magią — świadczy o tym i jej sposób poruszania się, i posługiwanie się zaklęciami: rozkazuje ona wrotom

„Kocioł szybował po niebie, a tłuste włosy Baby Jagi powiewały wraz z nim. Długi podbródek zakrzywiony w górę i wielki haczykowaty nos stykały się pośrodku. Miała małą siwą kozią bródkę i na skórze mnóstwo brodawek od jadu ropuch. Paznokcie w brązowych plamach były grube, ostro zakończone i tak zakrzywione, że nie mogła zacisnąć dłoni w pięść”. Zastanawiać może, dlaczego $\mathrm{w}$ przytoczonym opisie pojawiają się ropuchy — czy wiąże się to $\mathrm{z}$ wyobrażeniem pełnienia przez te płazy funkcji chowańców Baby Jagi (podobnie jak wierzono w okresie europejskich polowań na czarownice, zob. J.B. Russell, Krótka historia czarownictwa, przeł. J. Rybski, Wrocław 2003, s. 114; P. Rutkowski, Kot czarownicy. Demon osobisty w Anglii wczesnonowożytnej, Kraków 2012, s. 11, $15,16,20,148-150,153,155,175-177,190,201,204,209,222,240,241,421,423,424)$, czy też z wizją ich jadu jako składnika magicznych mikstur przez nią przygotowywanych.

${ }^{11}$ Rosyjskie bajki ludowe..., s. 79.

12 Pani Holle to kobieca postać demoniczna, ale waloryzowana pozytywnie. Mieszka pod ziemią, a Grimmowska baśń 24 przedstawia ją jako starą kobietę o ogromnych zębach. Karze ona za lenistwo, ale nagradza za pracowitość. W mitologii germańskiej jest panią zimy, dlatego w tejże baśni, kiedy w trakcie słania jej łóżka sypie się pierze, na ziemi pada śnieg. A. Szrejter (Demonologia germańska. Duchy, demony i czarownice, Gdańsk 2011, s. 129-135) nazywa ją też władczynią zaświatów, zmarłych (zdegradowaną formą skandynawskiej bogini Hel), ale ponadto ludzkiego życia i płodności. Dualizm ów jest dobrze widoczny we wspomnianej opowieści.

13 Zob. Z. Krzak, Od matriarchatu do patriarchatu, Warszawa 2007, s. 149; G. Lasoń-Kochańska, Dziewczynka, macocha, czarownica. Obraz kobiety w baśni, „Literatura Ludowa” 2011, nr 4/5, s. 24 . 
otworzyć się, a do mielenia pszenicy i wytłaczania oleju z maku wzywa trzy pary rąk. Ponadto jej „wiernymi sługami” są biały, czerwony i czarny jeździec, czyli dzień, słońce i noc ${ }^{14}$. Tajemnicza istota wykazuje jednak też cechy mogące budzić sympatię, a nawet współczucie. Musi zlecić Wasylisie oczyszczenie maku z ziemi, bo nasypał jej tam ,„[k]toś złośliwy” — niewykluczone więc, że Baba Jaga nieraz styka się z prześladowaniami, podobnie jak bardziej pospolite wiedźmy. Widać też, że brakuje jej towarzystwa, że czuje się samotna — pragnie, żeby dziewczyna $\mathrm{z}$ nią rozmawiała. Ludowy narrator wkomponował w obraz Baby Jagi również elementy humoru. Gdy Wasylisa chce swoją „gospodynię” o coś zapytać, ta odpowiada: „Pytaj, ale pamiętaj, że nie każde pytanie prowadzi do dobrego: za dużo będziesz wiedziała, prędko się zestarzejesz”. W tym kontekście jej groźby: „Nie lubię, żeby brudy z mojego domu wynoszono, i zjadam za bardzo ciekawych!"15, wywołują raczej uśmiech niż przerażenie.

Dzięki pomocy lalki, którą otrzymała od matki, Wasylisa wykonuje bezbłędnie i w terminie wszystkie prace, więc opuszcza chatkę Baby Jagi z upragnionym ogniem. Znamienne, że ,gospodyni”, dowiedziawszy się, iż jej tymczasowej służce pomaga błogosławieństwo matki (jak dziewczyna nazywa lalkę), żegna Wasylisę słowami: „Niepotrzebni mi są błogosławieni”16. Zdaje się więc całkowicie dystansować od wszelkich przejawów chrześcijaństwa czy w ogóle religijności, należeć do odrębnego porządku. Koresponduje to z elementarnym dla antropologii przeciwstawieniem magii i religii ${ }^{17}$. Baba Jaga dotrzymuje wszakże obietnicy — daje Wasylisie jedną z czaszek zdobiących płot. Okazuje się ona niespodziewanie dobroczynnym dla protagonistki darem: ogień z oczodołów doszczętnie spala niegodziwą macochę i jej córki ${ }^{18}$.

Inne oblicze ukazuje Baba Jaga w utworze nr 113 (33 w polskiej edycji), Dzikie gęsi. Według tej wersji nie ma bowiem w tej postaci żadnych cech przyja-

${ }^{14}$ Stąd C.P. Estés - może nieco zbyt pochopnie - wysnuwa wniosek, że Baba Jaga jest „władczynią istot ziemskich i niebieskich” (op. cit., s. 124).

${ }^{15}$ Rosyjskie bajki ludowe..., s. 80.

${ }^{16}$ Ibidem, s. 81. Jak wykazała A. Engelking (Klatwa. Rzecz o ludowej magii stowa, Warszawa 2010, s. 299-318), w kulturze ludowej błogosławieństwo to „lustrzane odbicie” klątwy. Jest aktem „udzielania dóbr za pomocą słowa” (ibidem, s. 299), działającym nawet jeśli nastawienie mówiącego ma charakter nieżyczliwy (podobnie jak w wypadku klątwy, co zaświadczyły baśnie Grimmów nr 25, 93 i 108). Błogosławieństwo wypowiada się zwłaszcza przy okazji trzech najważniejszych rites de passage — narodzin, zaślubin i śmierci. Motyw błogosławieństw (i klątwy) towarzyszących pierwszemu z tych obrzędów utrwalony został w Grimmowskiej baśni Śpiąa królewna.

${ }^{17}$ Zob. na przykład J.G. Frazer, Złota gałąź. Studia z magii i religii, przeł. H. Krzeczkowski, Kraków 2012, s. 16.

18 Omówiony dotąd fragment baśni C.P. Estés (op. cit., s. 101-153) analizuje w duchu jungowskim, przedstawiając go jako sekwencję zadań inicjacyjnych — od pogodzenia się ze śmiercią „zbyt dobrej matki” (ibidem, s. 110), przez zmierzenie się z ciemnością (to jest świadomością zła w świecie i w samej sobie) oraz z Czarownicą (złowrogim obliczem archetypu kobiecości - Wielkiej Bogini), po odzyskanie kontaktu z własną intuicją i ponowne uformowanie Cienia we własnej psychice. 
znych, a tytułowe ptaki, które jej służą, porywają małe dzieci. Nikczemność jej charakteru podkreślona zostaje brzydotą zewnętrzną — to istota „z gębą szpetną, nogami koślawymi" "19. W tej baśni odnajduje też odbiorca następny bardzo charakterystyczny element kojarzony z tą bohaterką: jej chatka spoczywa na kurzej stopce i stale się obraca. Podobny obraz Baby Jagi pojawia się w utworze nr 114 (34 w wydaniu polskim), Kniaź Daniła-Szaławiła. Jej chatka (tak stara, że ledwo stojąca) także opiera się na kurzej stopce, a kolejną istotną informacją jest, że należy przykazać owemu domostwu, by obróciło się we właściwą stronę ${ }^{20}$. Można w tym mechanizmie dopatrywać się animalizacji owej siedziby — postrzegania jej jako żywego stworzenia, jednego z posłusznych Babie Jadze zwierząt ${ }^{21}$. Elementem z kolei rzadziej spotykanym jest obecność w chatce przepięknej młodej kobiety (nazywanej jednym ze stale występujących w rosyjskich baśniach wyrażeniem „cud-dziewczyna”), która okazuje się córką tajemniczej istoty. Podobnie jak matka i ona włada magią: potrafi na przykład zamienić protagonistkę baśni w igłę - po to by ukryć jej przybycie przed Babą Jagą, charakteryzującą się, jak w baśni o Wasylisie, wyjątkowo wyczulonym węchem; dzięki niemu antagonistka natychmiast rozpoznaje, że w chacie był ktoś obcy. Mimo swojej potęgi zdaje się mieć jednak pewne ograniczenia: owszem, zjada ludzi, ale nie starych — ci są „nie na jej zęby”. Jest też „kuternogą z nosem zadartym do sufitu”22. W tej wersji wykazuje zatem znacznie więcej cech groteskowych, świadczących o prześmiewczym stosunku ludowego narratora do tej postaci.

W Kniaziu Danile-Szaławile nie sposób też odnaleźć jakichkolwiek pozytywnych aspektów Baby Jagi. To ona — określana mianem „złej wiedźmy” — postanawia sprowadzić nieszczęście na dzieci księżnej, tylko dlatego że jej się one „nie spodobały” ${ }^{23}$. Ponadto w wypadku tego tekstu słowa o pożeraniu ludzi nie są jedynie czczymi groźbami, ale zapowiadają w pełni realne niebezpieczeństwo. Matka „cud-dziewczyny” każe protagonistce usiąść na łopacie i stara się wepchnąć ją do pieca - zupełnie jak czarownica z Grimmowskiej baśni o Jasiu i Małgosi. Katarzyna, udając, że nie umie prawidłowo usiąść, skłania Babę Jagę do pokazania, jak należy to uczynić, i wydaje się, że „gospodynię” chatki spotka taki sam los jak jej odpowiednik zachodni - ale złowroga istota się uwalnia. Świetnie radzi sobie też — dzięki swoim ogromnym szponom — z gęstym zagajnikiem, który wyrasta ze szczotki zabranej z jej chaty przez córkę. Podobnie — tym razem przy użyciu zębów — tajemnicza istota przedziera się przez dąbrowę powstałą z czarodziejskiego grzebienia. Ostatecznie jednak ginie w ogniu -

${ }^{19}$ Rosyjskie bajki ludowe..., s. 86.

20 Ibidem, s. 89.

${ }^{21}$ Zob. W. Propp, Historyczne korzenie bajki magicznej, przeł. J. Chmielewski, Warszawa 2003, s. 61.

${ }^{22}$ Rosyjskie bajki ludowe..., s. 89, 90.

${ }^{23}$ Ibidem, s. 88. 
a właściwie w morzu ognistym, w które zamienia się magiczna chusta wyszywana złotem, także zabrana z chaty wiedźmy.

W zaprezentowanej właśnie baśni Baba Jaga nazywana jest „kuternogą”, częściej jednak towarzyszy jej przydomek „Kościana Noga”, pojawiający się na przykład w utworze nr 141 (41 w polskiej edycji), Niedźwiadek, Wąsal, Waligóra $i$ Wyrwidą - siłacze. Powracają tu elementy znane z poprzednich baśni: stojąca na kurzej nóżce chatka, której trzeba rozkazać, by obróciła się do gości drzwiami, stępa i thuczek w funkcji środków transportu, wielka zasobność domostwa tajemniczej istoty („na podwórku gęsi i kaczek, i indyczek — wszystkiego pod dostatkiem”), jej niepohamowana żarłoczność. Nowymi szczegółami są stałe obracanie się chatki, pies towarzyszący Babie Jadze oraz okoliczności jej pojawiania się: ,zaszumiało, zawirowało, w oczach zrobiło się zielono - ziemia się wybrzuszyła, spod ziemi kamień wychodzi, spod kamienia Baba Jaga Kościana Noga [...]"24.

W tej baśni tajemnicza istota wykazuje się też złośliwością i sadyzmem: częstowana kolejno przez Wąsala, Waligórę i Wyrwidęba obfitym posiłkiem, zjada niewiele, a resztę rzuca swojemu psu i twierdząc, że nie została stosownie ugoszczona, dotkliwie bije mężczyzn tłuczkiem. Ten motyw przypomina zachowanie karła z Grimmowskiej opowieści nr 166, Jaś mocarz. Wędrując przez podziemny świat, Iwan-Niedźwiadek trafia w końcu do pałacu, w którym znajduje „trzy dziewczyny przecudnej urody” — córki Baby Jagi, analogiczne do „cud-dziewczyny" z poprzedniej baśni. Jedna z nich podpowiada Iwankowi, żeby zaproponował ich złowrogiej matce „dwa złote jabłuszka na srebrnym spodeczku" 25 , a kiedy ona będzie próbowała je zjeść, zabrał leżący u jej wezgłowia miecz i ściął jej głowę. Trzeba to wszakże uczynić jednym zamachem, gdyż kolejna próba ożywia Babę Jagę. Sugeruje to labilny status tej bohaterki, jej egzystowanie w sferze pośredniej między życiem a śmiercią i niepodleganie zwykłym prawom natury.

W baśni nr 159 (52 w polskim wydaniu) Baba Jaga jest postacią poboczną. Mieszka „,[z]a siedmioma rzekami, za siedmioma górami, za rzeką ognistą"26, a porusza się nie w stępie, ale na magicznej kobyle. Co dzień oblatuje na niej dookoła cały świat. Hoduje też piękne klacze, których źrebaki są najszybszymi końmi, jakie można zdobyć. Jej dom — określany tylko tym ogólnym wyrazem, w omawianej baśni nie ma bowiem wzmianki o kurzej nóżce — otacza 12 słupów, na 11 zaś z nich znajduje się ludzka głowa. Za trzydniową służbę u Baby Jagi, polegającą na pasieniu klaczy, można dostać niezwykłego źrebaka pod warunkiem jednak, że żadne zwierzę się nie zgubi. Niełatwo to osiągnąć, bo tajemnicza istota rozmawia $\mathrm{z}$ końmi i specjalnie każe im się rozbiegać $\mathrm{w}$ różne strony — po to by uzyskać „ozdobę” na ostatni słup.

Według baśni Nikita Kołtoma i groźny car (nr 199 [61]) Baba Jaga skrywa w swojej chacie — oprócz znanej już z poprzednich utworów wielkiej obfito-

24 Ibidem, s. 119.

${ }^{25}$ Ibidem, s. 121.

${ }^{26}$ Ibidem, s. 162. 
ści pożywienia - magiczny gwizdek, którego dźwięk zmusza do tańca nie tylko wszystkich słyszących go ludzi, lecz także meble, sprzęty i naczynia. Jest to taniec zupełnie niekontrolowany, więc użycie gwizdka przez bohaterów doprowadza do ogromnych zniszczeń w pomieszczeniu. Powróciwszy do domu, Baba Jaga, za opróżnienie spiżarni i pozostałe szkody, chce się zemścić na protagoniście i jego bracie Timofieju, ale mężczyźni zdobywają nad nią przewagę siłą, co ostatecznie sprawia, że tajemnicza istota obiecuje spełnić każde ich życzenie. Proszą o wskazanie drogi do wody żywej (ożywiającej umarłych) i do wody uzdrawiającej leczącej rany (w innych rosyjskich baśniach nazywanej wodą martwą). Oślepiony wcześniej Timofiej odzyskuje dzięki niej oczy, a zwilżywszy je wodą żywą, znowu widzi. Po tym zdarzeniu zmienia się stosunek braci do Baby Jagi: dziękują jej, a komentujący ten fakt narrator nazywa ją nawet pieszczotliwie „staruszką"27.

W kolejnej baśni, Iwan carewicz, jego siostra i smok Gorynycz (nr 204 [62]), objawia się następna, równie charakterystyczna jak niezwykła cecha Baby Jagi: jej ogromne rozmiary i groteskowe proporcje ciała: nogi leżą w jednym kącie izby, głowa w drugim, usta sięgają podłogi, a nos — sufitu. Baśń ta jest istotna także dlatego, że w niej jako pierwszej występują dwie odrębne Baby Jagi. Potwierdza to domysł, jaki nasuwał się już przy analizie poprzednich baśni, w których przecież owe tajemnicze istoty niekiedy znacznie od siebie się różniły: Baba Jaga nie jest nazwą własną, określającą obiekt jednostkowy, ale pospolitą — nazwą kategorii postaci, swoistych „wiedźm wyższego rzędu”. Świadczy o tym również to, że w części rosyjskich przekazów oba człony tej nazwy pisane są małymi literami, a sięgając do etymologii, można je przetłumaczyć po prostu jako „przerażająca stara kobieta". Dlatego, jak podsumowuje Sibelan Forrester, powinniśmy mówić raczej o ,jednej z Bab Jag” (,a Baba Yaga”) niż o „tej jedynej Babie Jadze” (,the Baba Yaga") ${ }^{28}$.

O ile Baba Jaga z baśni o pięknej Wasylisie pełni funkcję polegającą na testowaniu protagonistki - w tym wypadku jej pracowitości — o tyle Baby Jagi z analizowanego przekazu są przede wszystkim pomocniczkami i donatorkami. Obie ugaszczają Iwana i jego siostrę, zamiast skąpo wydzielać jedzenie lub wręcz go odmawiać, obficie ich karmią i układają do snu. Co więcej, obdarowują ich dobrymi radami i magicznymi przedmiotami: niebieskim kłębuszkiem wskazującym właściwą drogę ${ }^{29}$ oraz ręcznikiem, którym machnięcie w jedną stronę wyczarowuje most, a w drugą — powoduje jego zniknięcie (by nie mogli z niego skorzystać wrogowie). Obie też oddają bohaterom pod opiekę po jednym psie,

27 Ibidem, s. 202.

28 S. Forrester, Introduction: Baba Yaga: The Wild Witch of the East, [w:] Baba Yaga: The Wild..., s. xxiii.

${ }^{29}$ Tego rodzaju przedmiot jest zapewne przetworzeniem mitologicznego motywu znanego z mitu o Ariadnie, Tezeuszu i labiryncie Minotaura. Zob. R. Graves, Mity greckie, przeł. H. Krzeczkowski, Kraków 2009, s. 303. 
a każdy z nich, jak się okazuje w dalszej akcji, wyczuwa „nieczystą siłę"30. To dodatkowo uwydatnia, że w omawianej wersji Baby Jagi nie mogą być istotami demonicznymi.

Przyjrzawszy się obrazom Bab Jag zawartym w baśniach zgromadzonych przez Afanasjewa, warto odnotować, jakie są ustalenia badaczy ludowych wierzeń słowiańskich na temat tego wyobrażenia. Bohdan Baranowski zalicza je do człekokształtnych demonów leśnych, nazywanych też jędzonami, babojędzami, jagami czy babami jagami — pisanymi właśnie tak, małymi literami, jako nomen appellativum — a przyjmujących postać odstraszającej wyglądem istoty płci żeńskiej, jednoznacznie wrogiej wobec ludzi, pragnącej ich krwi, a nawet porywającej i tuczącej dzieci, po to by je zjeść (jak w baśni o Jasiu i Małgosi). Z czasem wizerunek jędzy zespolił się z wyobrażeniem chrześcijańskiej czarownicy — wspólniczki diabła, tak że wyrazy „czarownica”, „,wiedźma”, ,jędza” „baba jaga" stały się synonimiczne ${ }^{31}$.

Aleksander Gieysztor też wymienia Babę Jagę pośród demonów leśnych i zwierzęcych. Zauważa, że w niektórych wersjach uznawana jest ona za panią lasu, częściej jednak za demona powiązanego ze śmiercią, groźnego dla położnic i dzieci ${ }^{32}$. Wątek ten rozwija Stanisław Urbańczyk, podkreślając, że według wierzeń Słowian człowiek najbardziej narażony był na wpływ demonów w przełomowych momentach w swoim życiu — a do takich z pewnością należą narodziny. Badacz ten wymienia babę jagę jako jedną z „boginek” mogących — wedle prezentowanego światopoglądu — „ukraść zdrowe i piękne dziecko, a podrzucić swoje niewydarzone" (odmieńca). Dlatego należało odpowiednio zabezpieczyć potomka, na przykład przez nadanie imienia lekceważącego (by stworzyć pozory małej wartości noworodka) lub wręcz przeciwnie — groźnego (by odstraszyć nadprzyrodzoną istotę) $)^{33}$.

Znacznie wyższy status w hierarchii nadnaturalnych bytów wyobrażanych przez Słowian przypisuje Babie Jadze Andrzej Szyjewski. Według niego jest ona „,̇eńskim bóstwem opiekuńczym sił leśnych, jej alternatywne miana to Leśna Baba, Buba albo Jędza”, co thumaczyć należy jako „Starucha Mąk” ${ }^{34}$. Zwykle ukazuje się - co do tego badacze są zgodni — jako stara, brzydka kobieta. Żyje w przyjaźni ze zwierzętami, towarzyszyć jej mogą zwłaszcza kruk, sowa, wilk, wąż albo — rzecz jasna — kot $^{35}$. W ustaleniach Szyjewskiego pojawia się motyw

${ }^{30}$ Rosyjskie bajki ludowe..., s. 206.

${ }^{31}$ B. Baranowski, W kręgu upiorów i wilkołaków, Łódź 1981, s. 165-166, 210-211.

32 A. Gieysztor, Mitologia Słowian, wstęp K. Modzelewski, posł. L. Słupecki, oprac. na podst. rkpsu A. Pieniądz, Warszawa 2006, s. 264.

33 S. Urbańczyk, Dawni Stowianie. Wiara i kult, Wrocław 1991, s. 163.

34 A. Szyjewski, Religia Stowian, Kraków 2003, s. 181.

35 Znaczące jest, że właśnie te zwierzęta towarzyszą Babie Jadze. Sowa to ptak prowadzący nocny tryb życia; kot — ssak nokturnalny, czyli szczególnie aktywny o świcie i o zmierzchu; wąż jest symbolem zła, szatana, a w dawniejszych wyobrażeniach — mocy chtonicznych; wilk — przysłowiowym wręcz wrogiem ludzkich siedzib (co utrwaliło się na przykład we frazeologizmie „Nie 
chatki na kurzej stopie, polowania na dzieci i pożerania ich, a także — znany z Afanasjewowskiej baśni nr 141 - motyw wycinania rzemieni z pleców dorosłych. Elementem, który nie pojawił się w wyborze baśni opracowanym przez Łużnego, jest duszenie zbłąkanych wędrowców długimi piersiami. Szyjewski wiąże Babę Jagę z prasłowiańskim żeńskim demonem leśnym, wywodzącym się z krainy zmarłych i patronującym inicjacji młodzieży ${ }^{36}$. W innym miejscu - powołując się na ustalenia Evela Gaspariniego ${ }^{37}$ — sugeruje możliwość upatrywania w Babie Jadze obrazu Wielkiej Bogini ${ }^{38}$. W jeszcze innym (za Ludwikiem Stommą ${ }^{39}$ ) wskazuje na ludzkie pochodzenie tej istoty: miałaby się nią stawać dusza kobiety zmarłej w połogu ${ }^{40}$. Jak podsumowuje:

gdy zbadamy przekazy ludowe dotyczące powstawania danych istot oraz ich zakresu funkcjonalnego, odpowiedzi wielokrotnie krzyżują się, tym samym postaciom przypisuje się różne funkcje i pochodzenie albo różne duchy zostają do siebie funkcjonalnie sprowadzone ${ }^{41}$.

Z Wielką Boginią — w jej trzecim wcieleniu, Staruchy, patronki śmierci wiąże Babę Jagę także Zygmunt Krzak (utożsamiając ją zarazem między innymi z germańską panią Holle, o czym była już mowa). Nazywa ją boginią-czarownicą, kontrolująca „śmierć i odrodzenie, cykle księżyca, energię słońca, burze i światło oraz ludzką seksualność"42. Odnotowuje, że w folklorze rosyjskim i polskim postrzegano ją jako „olbrzymkę ludożerczynię”, „starą złą czarownicę zjadającą ludzi, szczególnie dzieci" i zdolną zamieniać się w różne zwierzęta - ale również

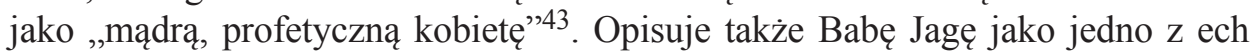
pradawnego matriarchatu, które przetrwało w folklorze słowiańskim stosunkowo długo. Oprócz cech i motywów wymienionych dotąd wskazuje, że w drzwiach jej chatki w miejscu zasuwy znajduje się „ludzka noga, w miejscu rygla — ręce, w miejscu zamka — twarz z ostrymi zębami”, a samo wnętrze wypełniają „,elemen-

wywołuj wilka z lasu"); krukowi zaś w antyku przypisywano zdolność przepowiadania przyszłości, a w symbolice chrześcijańskiej jest on „alegorią samotności” (J.E. Cirlot, Stownik symboli, przeł. I. Kania, Kraków 2012, s. 207) - uczucia nieobcego Babie Jadze, jak wykazała analiza baśni o pięknej Wasylisie. Ponadto „[u] wielu ludów Wschodu i Zachodu kruki uważane są ptaki złowróżbne, żałobne, wieszczące nieszczęścia, choroby, zarazy, wojnę i śmierć [...]" (W. Kopaliński, Słownik symboli, Warszawa 2006, s. 169). O bogatej symbolice tych zwierząt (zwłaszcza węża) świadczy chociażby długość artykułów hasłowych, jakie poświęcił im J.C. Cooper (Zwierzęta symboliczne i mityczne, przeł. A. Kozłowska-Ryś, L. Ryś, Poznań 1998, s. 117-120, 131-133, 257-259, 281-289, 294-296).

36 A. Szyjewski, op. cit., s. 181.

${ }^{37}$ E. Gasparini, Il Matriarcato slavo. Antropologia culturale dei protoslavi, Firenze 1973.

38 A. Szyjewski, op. cit., s. 125.

${ }^{39}$ L. Stomma, Antropologia kultury wsi polskiej XIX w., Warszawa 1986.

${ }^{40}$ A. Szyjewski, op. cit., s. 163. Na temat owej płynności słowiańskich wyobrażeń ludowych zob. na przykład L. Moszyński, Dlaczego naukowe opisy prasłowiańskich wierzeń są tak różnorodne, „Studia Mythologica Slavica” 1998, nr 1.

${ }^{41}$ A. Szyjewski, op. cit., s. 162.

42 Z. Krzak, op. cit., s. 149.

${ }^{43}$ Ibidem, s. 328. 
ty chtoniczno-infernalne, świadczące o bestialskich morderstwach dokonywanych na przybyszach". Ponadto wspomina o ślepocie Baby Jagi (lub o bólu jej oczu), co koresponduje z tym, że wiedźmy z baśni zebranych przez Grimmów „mają czerwone oczy i nie widzą dobrze na odległość [... "⒋ Dopatruje się w niej też pani fauny, gdyż żyje ona w harmonii nie tylko ze swoimi chowańcami, lecz także z dzikimi zwierzętami ${ }^{45}$. Natomiast to, że ,[p]osługuje się łopatą, za pomocą której wsuwa dzieci do pieca, [...] pozwala dopatrywać się w niej echa dawnej kapłanki”. Jednocześnie Krzak odnotowuje, że ,[z]namiona dobrej Baby Jagi zachowały się w niektórych czarodziejskich bajkach" 46 — co można było dostrzec, analizując zbiór Afanasjewa. O kapłańskich funkcjach Baby Jagi wspomina też Grażyna Lasoń-Kochańska, łącząc ją z postacią pani Trude, występującej w baśni 43 ze zbioru Grimmów: „Jako kapłanka inicjacji młodzieży, demoniczna starucha jest strażniczką żeńskich, ciemnych mocy, znanych z matriarchalnych mitologii”"47.

Postać Baby Jagi łączy z Wielką Boginią także Maciej Czeremski. Widząc w niej czwarte $\mathrm{z}$ wyodrębnionych przez Ericha Neumanna ${ }^{48}$ archetypowych wcieleń kobiecości, nazywane po prostu Starą Wiedźmą, i podążając za analizą dokonaną przez Władimira Proppa ${ }^{49}$, wskazuje liczne świadectwa powiązania tej bohaterki z żywiołem śmierci. Jeden z jej najbardziej typowych atrybutów, kościana noga, jest według badacza ,trupią wersj[a] uniwersalnego symbolu kulawych istot chtonicznych" ${ }^{\text {50. }} \mathrm{Z}$ kolei zajmowanie przez jej ciało całej przestrzeni chatki może świadczyć o tym, że chatka ta jest w istocie po prostu grobem. Dodać można, że sugestię powiązania Baby Jagi z zaświatami stanowi także to, że w niektórych baśniach jej domostwo znajduje się pod ziemią — „na tamtym świecie” — o czym była już mowa. Trudno zaś się zgodzić z kategorycznym: „Starucha nie widzi odwiedzających ją postaci, zawsze rozpoznaje je dzięki węchowi" ${ }^{51}$. Pośród przeanalizowanych baśni motyw ów pojawił się tylko w tej o pięknej Wasylisie, użycie kwantyfikatora wielkiego w zacytowanym zdaniu nie wydaje się

${ }^{44}$ W. i J. Grimm, Baśnie dla dzieci i dla domu, il. O. Ubbelohde, przeł. E. Pieciul-Karmińska, Poznań 2010, t. 1, s. 93. Według wariantu przytaczanego przez C.P. Estés (op. cit., s. 106) „oczy Baby Jagi zamieniają się [...] w czerwone węgle”, gdy wygłasza ona groźby.

45 W. Propp (op. cit., s. 75-79) każe na tej podstawie wiązać Babę Jagę z kompleksem wyobrażeń składającym się na postać Potnia Theron (Pani Dzikiej Zwierzyny lub, w innym tłumaczeniu, Pani Dzikich Stworzeń), której wcieleniem była także między innymi grecka Artemida (rzymska Diana), gdy przypisano jej cechy najwyższej bogini-nimfy archaicznych społeczeństw totemicznych, czczonej między innymi na Krecie. Zob. R. Graves, op. cit., s. 70-71.

46 Z. Krzak, op. cit., s. 373.

${ }^{47}$ G. Lasoń-Kochańska, Odbaśnianie czarownicy. Kobieca starość wobec tradycji kultury, [w:] Dojrzewanie do petni życia. Starość w literaturze polskiej i obcej, red. S. Kruk, E. Flis-Czerniak, Lublin 2006, s. 646.

48 E. Neumann, Die grosse Mutter. Der Archetyp des grossen Weiblichen, Zürich 1956.

49 W. Propp, op. cit., s. 69-70.

${ }^{50}$ M. Czeremski, Baba Jaga i królewny. Postać kobiety w bajce magicznej, [w:] Kobiety i religie, red. K. Leszczyńska, A. Kościańska, Kraków 2006, s. 514-515.

${ }^{51}$ Ibidem, s. 516. 
więc zasadne. Warto zaś odnotować — czego Czeremski nie czyni - że Propp sugeruje, iż u Baby Jagi ślepota mogłaby oznaczać niewidzialność:

przez ślepotę nie rozumie się [...] [tylko] braku wzroku. Łacińskie „caecus” na przykład nie oznacza wyłącznie aktywnej ślepoty ([...] [niewidzenia]), lecz także, by tak rzec, ślepotę pasywną ([...] [niewidoczność] — „caecanox” — ,ślepa noc [to jest ciemna, taka, w której trakcie nic nie widać — D.U.]"). Z tym samym mamy do czynienia w przypadku niemieckiego ,ein blindes Fenster" [to jest elementu ściany przypominającego okno, lecz bez otworu i szyb - D.U.] $]^{52}$.

Trzeba przy tym też wskazać, że w wielu wyobrażeniach mitologicznych (między innymi północnoamerykańskich i afrykańskich) na zapach żywych osób szczególnie wrażliwi są umarli — i tak jak trupi zapach wydaje się żywemu człowiekowi wstrętny, tak dla nieboszczyka woń żywego człowieka jest odorem ${ }^{53}$.

Zarówno poczynione analizy, jak i zreferowane ustalenia badawcze potwierdzają zacytowaną na początku tezę o bogactwie i wieloznaczności postaci Baby Jagi. W omówionych utworach pojawił się każdy z trzech wymienianych przez Proppa typów tej bohaterki: Ofiarodawczyni, Porywaczka i Wojowniczka ${ }^{54}$. Bywa ona, jak pospolita wiedźma w większości baśni, po prostu antagonistką głównego bohatera, istotą nadprzyrodzoną jednoznacznie wrogą ludziom. Ale bywa też pomocnicą, donatorką, a przede wszystkim tą, która poddaje protagonistę próbie i prowokuje jego rozwój. Sprawdza pracowitość, wytrwałość, cierpliwość, gospodarność - cechy bardzo cenione i niezwykle przydatne w życiu ludu. Zwłaszcza w baśni o pięknej Wasylisie widać jej rolę jako osoby przeprowadzającej inicjację młodego bohatera, będącą warunkiem koniecznym włączenia go do społeczności jako jej pełnoprawnego członka ${ }^{55}$. Czarownica, demon lub bogini, która raz walczy z protagonistą, raz mu pomaga i obdarowuje go, a jeszcze kiedy indziej testuje postać Baby Jagi mieści w sobie niemało. Ma ona wiele obliczy, dlatego też - co warto na koniec tej części jeszcze raz podkreślić — można mówić o wielu babach jagach czy raczej (jednak — ze względu na szacunek, jakim zdaje się cieszyć tego rodzaju postać w świadomości ludowych narratorów) Babach Jagach.

Oprócz nich często występują w rosyjskich baśniach bardziej pospolite istoty żeńskie władające magią, określane po prostu mianem wiedźm lub czarownic. Mogą one należeć do rodziny protagonisty, częściej jednak żyją na uboczu ludzkiej społeczności, w odosobnieniu, w mrocznym lesie. Nierzadko bywają podkreślane ich żarłoczność i okrucieństwo, na przykład przez kilkakrotne powracanie narratora do motywu zębów (baśn 93 [28]) lub informację o niewahaniu się przed przyło-

52 W. Propp, op. cit., s. 71-72.

53 Zob. ibidem, s. 62-63.

${ }^{54}$ Ibidem, s. 50. Typologię tę — na podstawie najnowszych badań rosyjskich — uzupełnia I. Rzepnikowska (op. cit., s. 93), pisząc o odmianach Baby Jagi-donatorki: doradczyni, władczyni sił przyrody i świata zwierząt oraz opiekunce, a także o negatywnych wcieleniach tej postaci, takich jak „porywaczka dzieci, władczyni podziemnego carstwa, mścicielka i zła czarownica”. Przegląd jeszcze innych propozycji dotyczących genezy i interpretacji postaci Baby Jagi zob. V. Wróblewska, , Od potworów do znaków pustych". Ludowe demony w polskiej literaturze dla dzieci, Toruń 2014, s. 51-61.

${ }^{55} \mathrm{Na}$ ten temat zob. J. Zipes, op. cit., s. xi; S. Forrester, op. cit., s. xxxix. 
żeniem ręki do zbrodni (baśń 295 [83]). Mimo typowego dla wiedźm odizolowywania się od ludzi często powracającym w baśniach motywem jest podszywanie się tych postaci pod człowieka w celu uzyskania osobistych korzyści, zaznania wygodnego życia, a przy tym zaszkodzenia społeczności. Tak dzieje się w baśni nr 260 (74 w polskiej edycji), w której — co warto odnotować — antagonistka ginie w sposób klasyczny dla postaci omawianego rodzaju: spalona na stosie. Zdarza się też, że wiedźmy polują na dzieci, jak Czuwilicha z baśni 112 (32). Przy tym wszakże — tak jak Baby Jagi - miewają własnych potomków, co zasługuje na szczególną uwagę. Motyw ten pojawia się w baśniach stosunkowo często, mimo że typowe wyobrażenie czarownicy zakłada zwykle jej niezamężność i bezdzietność ${ }^{56}$. Zagadkowe jest więc pochodzenie latorośli (w baśniach prawie zawsze właśnie córki, niemal nigdy syna - wyjątkiem Grimmowski utwór nr 197). Trudno zakładać, by była ona przysposobionym ludzkim dzieckiem, edukowanym i ćwiczonym przez wiedźmę w magicznym rzemiośle, skoro postać tę ludowe opowieści przedstawiają zwykle jako reprezentantkę odrębnego gatunku. Czyżby więc reprodukcja baśniowych czarownic miała charakter partenogenetyczny? $\mathrm{Na}$ to pytanie analizowane teksty nie dają jednoznacznej odpowiedzi.

Poczynione zestawienie unaocznia, że rosyjskie baśniowe wiedźmy/czarownice wykazują wyłącznie negatywne cechy Baby Jagi, które w dodatku się potęgują. Można więc powiedzieć, że tego typu postacie są po prostu bardzo zredukowanym, pozbawionym śladów pochodzenia z dawniejszych wierzeń, wariantem tajemniczej istoty opisanej wcześniej.

\section{Kościej Nieśmiertelny i inni czarownicy}

Pośród występujących w rosyjskich baśniach męskich postaci obdarzonych nadprzyrodzonymi mocami szczególne miejsce zajmuje Kościej Nieśmiertelny. Jego imię pochodzi od słowa „kość” (ros. кость), co — podobnie jak kościana noga Baby Jagi — wskazuje na jego związek z zaświatami. Egzystencja Kościeja nie jest życiem w ludzkim rozumieniu tego słowa, a jego „nieśmiertelność” wynika ze specjalnych magicznych zabiegów. Jak podaje Mike Dixon-Kennedy w encyklopedii rosyjskich mitów i legend, Kościeja nie można zabić, ponieważ jego dusza nie znajduje się w ciele, ale została ukryta gdzie indziej ${ }^{57}$. Ten właśnie element okazuje się dystynktywny dla omawianego bohatera.

${ }^{56}$ Zob. na przykład M. Czeremski, op. cit., s. 516; por. G. Lasoń-Kochańska, Odbaśnianie czarownicy..., s. 644: „Baśniowe i rzekome [rzeczywiste] czarownice były zawsze odszczepieńcami, żyły poza nawiasem kultury i psychologii. Z zasady nie asymilowały się ze wspólnotą, mieszkały samotnie, na obrzeżu wsi lub w lesie. Nie miały męża i nie szukały akceptacji innych, wykraczając poza przewidziany dla kobiety, społeczny i obyczajowy porządek. Zrzucając wszelkie więzy, stanowiły swoistą postać żeńskiej anarchii, a niekiedy stawały się wręcz nieprzewidywalne".

57 M. Dixon-Kennedy, Encyclopedia of Russian and Slavic Myth and Legend, Santa Barbara 1998, s. 154. 
Baśnią ze zbioru Afanasjewa, w której Kościej odgrywa najistotniejszą rolę, jest ta o numerze 158 (51). Mimo że o randze Nieśmiertelnego w tym utworze mówi już sam jego tytuł, ludowa narracja nie uwzględnia informacji o wyglądzie tej tajemniczej istoty. Wiadomo tylko, że — znów podobnie jak Baba Jaga — porusza się ona, lecąc. Pojawia się ,[n]ie wiadomo skąd” i porywa Wasylisę Kirbitjewną, narzeczoną Iwana-carewicza, uwolnioną niewiele wcześniej z wieży. Podobnie jak Baba Jaga ma niezwykle wyczulony węch — od razu wyczuwa obecność obcych. Inaczej jednak niż tamta istota nie mówi po prostu o zapachu człowieka, ale o pochodzeniu bohaterów: ,ruskie powietrze w oczy się rzuca, do ust pcha" ${ }^{58}$. Analogiczne słowa w rosyjskich baśniach magicznych wypowiadają smoki, o których będzie tu jeszcze mowa ${ }^{59}$. Stwierdzenia takie były charakterystyczne, jak pamiętamy, dla Grimmowskiego gryfa (baśń 165) i diabła (baśń 29).

Zgubę na swojego porywacza sprowadza jego ofiara — za radą Bułata wypytuje Kościeja, gdzie została ukryta jego śmierć. Czarownik najpierw dwukrotnie próbuje oszukać Wasylisę, ale za trzecim razem (jak to w baśniach bywa) wyjawia prawdę: ,na morzu, na oceanie jest wyspa, na tej wyspie dąb stoi, pod dębem kufer jest zakopany, w kufrze zając, w zającu — kaczka, a w kaczce — jajko, i w tym jajku — śmierć moja!"60. Zguba czarownika okazuje się więc zabezpieczona aż siedmiokrotnie (morze - wyspa — dąb - kufer — zając — kaczka — jajko), a liczba ta, jak wiadomo, ma szczególne znaczenie, najczęściej wiązane z nieskończonością ${ }^{61}$. Przywodzi też na myśl rosyjskie matrioszki — kilka lub nawet kilkanaście drewnianych różnobarwnych laleczek włożonych jedna w drugą, od największej na wierzchu do najmniejszej w samym wnętrzu. Istotne jest także, co bohaterowie baśni czynią, zdobywszy jajko z niezwykłą zawartością. Nie rozbijają go - prawdopodobnie dlatego że wiedzą, iż nie mają odpowiedniej mocy ani narzędzi, aby zniszczyć duszę Kościeja. Powracają więc do jego siedziby i uderzają go jajkiem w czoło. Dopiero w ten sposób zły czarownik ginie — zadawszy ostateczny cios niejako samemu sobie ${ }^{62}$.

Oczywiście nie przypadkowo ostatnią warstwą ukrywającą duszę Kościeja jest jajko: uniwersalny w wielu kulturach symbol życia, a w chrześcijaństwie — zwycięstwa nad śmiercią, zmartwychwstania ${ }^{63}$. Motyw tego obiektu każe też

${ }^{58}$ Rosyjskie bajki ludowe..., s. 154, 155.

${ }^{59}$ W niektórych źródłach sam Kościej jest zresztą opisywany jako smok, a także — co potwierdzają wskazane już paralele - męski aspekt Baby Jagi. Zob. Encyclopedia of Russian and Slavic..., s. 155.

${ }^{60}$ Rosyjskie bajki ludowe..., s. 156.

${ }^{61}$ Warto odnotować, że podobny motyw oddzielenia własnej duszy od ciała i jej siedmiorakiego ukrycia (w tym wypadku rozszczepienia na siedem części) wprowadziła J.K. Rowling do popularnego cyklu o Harrym Potterze, wplatając w fabułę teorię horkruksów.

62 Podobnie czyni Lord Voldemort, rzucając na Harry’ego mordercze zaklęcie. Nie wie, że gdy pierwszy raz próbował zabić chłopca, cząstka jego duszy wniknęła w ofiarę i tak Harry stał się niezaplanowanym przez Czarnego Pana horkruksem. Finalnie więc czarownik bynajmniej nie uśmierca bohatera, lecz jedynie cząstkę samego siebie w nim żyjącą.

63 Zob. W. Kopaliński, op. cit., s. 110-111; J.E. Cirlot, op. cit., s. 166-167. 
kojarzyć Kościeja z czarownikiem z Grimmowskiej baśni 46, Ptak dziwak — odpowiednikiem Sinobrodego z wersji Charles'a Perraulta. Czarownik ten daje bowiem porwanej dziewczynie jajko i przykazuje: „Strzeż tego jajka i noś je najlepiej cały czas ze sobą, bo gdyby się zgubiło, mogłoby się stać wielkie nieszczęście"64. Właśnie na tym przedmiocie osadza się krew, zdradzając nieposłuszeństwo kolejnych dwóch narzeczonych antagonisty. Ostatecznie jednak zostaje powiedziane tylko, że ginie on w swoim domu, podpalonym przez braci i innych krewnych trzeciej narzeczonej. Nie sposób wszak wykluczyć, że śmierć owa następuje dlatego, że w ogniu zniszczone zostało właśnie jajko — schowane wcześniej przez wspomnianą trzecią dziewczynę. Motyw ukrycia śmierci Kościeja w jajku można powiązać także z Grimmowską baśnią nr 197, Krysztatowa kula, w której zdobycie tytułowego przedmiotu - umieszczonego w ognistym jaju, znajdującym się w ognistym ptaku wylatującym z brzucha zabitego tura — przynosi zgubę złemu czarownikowi ${ }^{65}$.

Nieco odmiennie rysuje się obraz omawianej postaci w kolejnej baśni ze zbioru Afanasjewa, nr 159 (52). W niej tytułową bohaterką nie jest czarownik, ale Maria Moriewna, „przepiękna królewna”, ukochana Iwana-carewicza. Okazuje się ona protagonistką o zainteresowaniach i uzdolnieniach zupełnie sprzecznych z tradycyjną rolą przypisywaną kobietom: zna się na strategii i taktyce wojskowej, potrafi dowodzić armią i wygrywać bitwy nawet z licznym wrogiem. Autentycznie też lubi to zajęcie: zaledwie ,jakiś tam czas"66 po ślubie znowu odczuwa przemożną chęć, aby wyruszyć na wojnę. W tym momencie akcji odwrócenie tradycyjnych ról jeszcze się pogłębia: tak jak w przytaczanych przed chwilą baśniach o czarowniku/Sinobrodym to ten złowrogi mężczyzna zakazywał porwanym dziewczynom zaglądania do jednej z komnat, tak w tym tekście przestrogę

${ }^{64}$ W. i J. Grimm, op. cit., t. 1, s. 235.

65 Jest to wątek w międzynarodowej systematyce określany jako „Serce ogra (diabła) w jaju” (na jego temat zob. A. Mianecki, Jajo w wybranych watkach ludowych bajek magicznych, [w:] Mit, prawda, imaginacja, red. P. Kowalski, Wrocław 2011) lub jako „Dusza potwora w jaju (dusza zewnętrzna)” (J. Krzyżanowski, Polska bajka ludowa w układzie systematycznym, wyd. 2, rozszerz., Wrocław 1962, t. 1, s. 86). Więcej o tego rodzaju fabułach zob. J. Frazer, Dusza zewnętrzna w baśniach ludowych, [w:] idem, Złota gałąź... Według Frazera wątek ten ,powtarza się w rozmaitej postaci [...] od Hindustanu po Hebrydy", w tym na przykład w opowieściach indyjskich (dusza czarownika w papużce), starożytnej i nowożytnej Grecji, między innymi tej o Meleagrze (dusza w głowni), o Nisusie, królu Megary (dusza we włosie) lub w bardziej współczesnej — o czarowniku, którego życie zależy „od trzech gołębi znajdujących się w brzuchu dzika” (ibidem, s. 489). Podobnie „[w]e współczesnej rzymskiej wersji baśni O Aladynie i jego czarodziejskiej lampie”, aby spowodować śmierć czarownika, należy położyć na jego poduszce klejnot ukryty w głowie ptaka, znajdującej się w głowie zająca, usytuowanego z kolei w środkowej głowie siedmiogłowej hydry (ibidem, s. 490); oraz w Baśniach z tysiaca i jednej nocy (dusza dżina w gardle wróbla, on w pudełku, ono w siedmiu innych, te - w siedmiu skrzyniach, zamkniętych w marmurowym kufrze, wrzuconym do oceanu) (ibidem, s. 494). Znana jest też skandynawska baśń o olbrzymie, który nie miał serca (zob. ibidem, s. 493), kreatywnie przetworzona przez J.K. Rowling w Baśniach barda Beadle'a.

${ }^{66}$ Rosyjskie bajki ludowe..., s. 160. 
tego rodzaju wygłasza kobieta, kierując ją do swojego męża. Iwan oczywiście nie potrafi oprzeć się pokusie, natychmiast po wyjeździe żony zagląda do zakazanego pomieszczenia i właśnie tam widzi Kościeja Nieśmiertelnego, podwieszonego na dwunastu łańcuchach. Można z tego wysnuć wniosek, że Maria Moriewna jest potężniejsza nawet od tak złowrogiego czarownika - skoro była w stanie go uwięzić i kontrolować (jeśli wierzyć słowom samego więźnia) przez 10 lat, pozbawiając go jedzenia i picia. Że zaś Kościej przetrwał równie długi czas bez jakiegokolwiek pożywienia, świadczy o wielkości jego mocy oraz podkreśla jego nieludzkość, niezależność od zwykłych praw natury i życia. Już trzy wiadra wody — podane przez nieświadomego konsekwencji Iwana — pozwalają Kościejowi odzyskać pełnię sił, zniszczyć wszystkie łańcuchy, wylecieć przez okno, dogonić Marię Moriewnę i ją porwać.

Po długiej wędrówce carewicz odnajduje żonę i z nią odjeżdża, ale zdarzenie to wyczuwa na odległość magiczny, mówiący ludzkim głosem koń czarownika. Dwa razy Kościej wybacza Iwanowi próbę odzyskania Marii, odwdzięczając się za to, że carewicz napoił go wodą, ale za trzecim razem bez skrupułów rozrywa go na kawałki. Ten element fabuły jest kolejnym dowodem na okrucieństwo, mściwość i bezwzględność większości baśniowych postaci władających magią.

Wiedząc zapewne o magicznych sposobach przywracania umarłych do życia, Kościej dodatkowo zabezpiecza szczątki swojej ofiary: chowa je w beczce, którą skuwa łańcuchami i wrzuca do morza. Iwana ratują jednak szwagrowie - trzej dzielni młodzieńcy potrafiący przybierać postać ptaków: orła, sokoła i kruka (lub może odwrotnie: czarodziejskie ptaki zdolne oblekać się w człowieczy kształt). Ożywiony Iwan może pokonać Kościeja, zdobywszy takiego samego magicznego konia, jakiego posiada przeciwnik. Ostatecznie Kościej ginie typową śmiercią czarownika - spalony na stosie. Analogicznym do poprzedniej baśni o Kościeju elementem fabuły jest to, że wiedzę, jak pokonać porywacza, na prośbę protagonisty zdobywa uprowadzona bohaterka. Obie baśnie potwierdzają też charakterystyczną dla tego gatunku zasadę, że do zwyciężenia antagonistów władających magią zwykle niezbędne jest użycie magicznych środków lub skorzystanie ze wsparcia czarodziejskich pomocników (jak na przykład ptasi szwagrowie Iwana) - a więc poniekąd tymczasowe stanie się postacią należącą do interesującej nas kategorii.

Wzmianka o Kościeju pojawia się jeszcze w baśni nr 270 (76). Jej bohaterką jest królewna zaklęta przez niego w żmiję, dlatego że nie chciała go poślubić. Po siedmiu latach, dzięki wytrwałości będącego protagonistą tego utworu Kozaka, który odnalazł ołowiane cesarstwo, zaklęcie przestaje działać. Sam Kościej nie należy jednak do postaci działających w tej baśni, nie jest tu też rozwijany wątek jego nieśmiertelności. Warto zaś odnotować, że zarysowana fabuła wykazuje podobieństwo do jednej z najbardziej rozbudowanych baśni Grimmowskich Szklana trumna (nr 163). 
Podobnie szkicowo jak wizerunek Kościeja z utworu nr 270 jawią się w rosyjskich baśniach magicznych obrazy innych mężczyzn (czy lepiej: istot, co do których można się domyślać, iż są płci męskiej) władających magią. W tekście wspomnianej już baśni nr 112 (32) wiedźma Czuwilicha wyprasza cienki głosik od czarownika, jednak nie zostaje on w żaden sposób scharakteryzowany. W baśni nr 311 (90) protagonista, wysłany do starca Ponuraka, by nauczyć się pisać i czytać, zamiast tego uczy się latać. Można więc się domyślać, że starzec ma pewne magiczne umiejętności. Kiedy jednak bohater wpada w gniew i grozi agresją, Ponurak próbuje go uspokoić nie mocą, lecz zwykłym błaganiem oraz obietnicą pieniędzy.

Motyw magicznej edukacji występuje też w baśni 252 (71), Nauczyciel i uczeń, podobnej do Kuglarza i jego mistrza (nr 68) ze zbioru braci Grimm. Tytułowy nauczyciel to „wszechwiedzący mędrzec” uczący „rozumieć język ptaków,

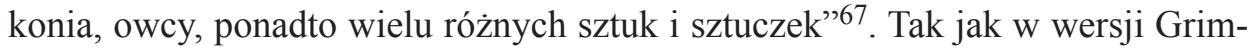
mów pojawia się tu motyw próby wymagającej rozpoznania właściwej osoby lub przedmiotu: ojciec pragnący odzyskać syna po zakończeniu przezeń edukacji musi zidentyfikować go pośród 30 jednakowych młodzieńców, koni i gołębi. W dalszej części opowieści, znów jak w zbiorze Grimmów, chłopak daje dowód, że sam stał się czarownikiem: trzykrotnie przemienia się w konia, aby umożliwić ojcu przeprowadzenie korzystnej transakcji (w tekście niemieckim była to najpierw transformacja $\mathrm{w}$ psa, a potem $\mathrm{w}$ wierzchowca). Warunkiem jego powrotu do domu jest brak uzdy, o czym doskonale wie nauczyciel, będący klientem ojca protagonisty za trzecim razem. Oferując dodatkową sumę za uzdę, więzi byłego ucznia w postaci zwierzęcia. Chłopaka ratuje - nieświadomie - siostra czarownika, litując się nad zmęczonym rumakiem i zdejmując mu krępującą uprząż. W trakcie pogoni nauczyciela za uczniem następuje znany również z Grimmowskiej wersji cykl przemian, w którego wyniku uczeń ostatecznie dowodzi swojej wyższości nad nauczycielem ${ }^{68}$.

Obrazu postaci czarowników z baśni zgromadzonych przez Afanasjewa dopełnia ten z utworu nr 354 (114), należącego do cyklu opowieści o nieboszczykach. Bohater ów dręczył mieszkańców wsi, dopóki żył, a po swojej śmierci (od której, jak widać, nie uchroniła go magiczna moc) stał się budzącym postrach

67 Ibidem, s. 239.

${ }^{68}$ Należy odnotować, że postać czarownika z tych baśni dowodzi też ich analogiczności do łużyckiej legendy o Krabacie, chłopcu podejmującym naukę u młynarza władającego czarną magią. Legenda ta stała się inspiracją licznych powieści, takich jak skierowany do odbiorcy dziecięcego Mišter Krabat (Mistrz Krabat, 1954; pol. Mistrz Krabat - dobry tużycki czarodziej, 1971) serbołużyckiego malarza i pisarza M. Nowaka-Njechorńskiego; Čorny młyn (Czarny młyn, 1968) kolejnego serbołużyckiego twórcy, J. Brězana; oraz najsłynniejszej i najbardziej obszernej, pióra niemieckiego autora O. Preusslera, zatytułowanej po prostu Krabat (1971, pol. 1976), klasyfikowanej jako literatura young adult (obejmująca obecnie czytelników w wieku od 15 do 25 lat; zob. M. Cart, From Insider to Outsider: The Evolution of Young Adult Literature, „Voices from the Middle” 2001, nr 2, s. 95) i uhonorowanej licznymi nagrodami w tej kategorii. 
upiorem. Wykazuje się pychą i głupotą, przechwalając się swoją wszechmocnością i przy tym nieopatrznie wyjawiając protagoniście - nie lękającemu się go żołnierzowi - sposób na swoje unicestwienie. Orientując się, jakie niebezpieczeństwo na siebie sprowadził, upiór chce żołnierza rozszarpać, ale w tym momencie pieje kur, co — jak zazwyczaj w wypadku nadnaturalnie ożywionych nieboszczyków - odbiera antagoniście nienależne mu siły żywotne.

Sposób, w jaki czarownik zostaje pokonany — zgodnie z własnymi wskazówkami - wiele mówi o ludowym przekonaniu na temat nienaturalności i budzącej wstręt specyfice egzystencji osób rzekomo parających się magią. Nie wystarczy użyć charakterystycznej w odniesieniu do domniemanych czarownic metody: oczyszczenia ogniem. Podpaliwszy ciało mężczyzny na stosie, protagonista i inni mieszkańcy wsi muszą jeszcze walczyć ze żmijami, robakami i rozmaitymi gadami, które wychodzą z pękniętej pod wpływem gorąca wątroby czarownika. Ten makabryczny turpistyczny opis jest odzwierciedleniem tradycyjnego poglądu o ohydzie magii jako całkowicie sprzecznej z doktryną chrześcijańską. Warto też odnotować, że w badanym przez Edwarda E. Evansa-Pritcharda afrykańskim plemieniu Zande źródło czarostwa (witchcraft) — wrodzonej mocy, przekazywanej z pokolenia na pokolenie na zasadzie dziedziczenia (opozycyjnej wobec czarnoksięstwa [sorce$r y$ ], wymagającego zastosowania odpowiednich specyfików) — ma postać materialną: mieści się w ciele czarownika, zazwyczaj w jego żołądku lub właśnie w wątrobie, ,jako owalna, ciemna opuchlizna, zawierająca czasem drobne przedmioty, lub jako włochata kulka z zębami"69. Analogia ta stanowi jeszcze jedno świadectwo uniwersalności wielu pierwotnych wyobrażeń, powtarzających się nawet w bardzo odległych od siebie kręgach kulturowych.

Motyw swoistego pojedynku między żołnierzem a czarownikiem (choć tym razem żywym) pojawia się także w baśni 378 (127) o wymownym tytule Trafita kosa na kamień. Jej fabuła pokazuje niezaświadczoną w dotąd przeanalizowanych utworach cechę postaci władających magią: chciwość (choć pewną jej sugestią mogły być skarby zgromadzone przez wiedźmy z Grimmowskich baśni nr 116 i 193, a także przez karły). We wsi kontrolowanej przez czarownika każdy, kto wyprawia wesele, nawet najbiedniejsza osoba, musi zawieźć tyranowi pieniężny podarunek. Do realizacji zaś własnych celów mag wykorzystuje zwierzęta: byka, niedźwiedzia, zająca i kruka, co pozwala wiązać go z Babą Jagą w jej aspekcie Potnia Theron - Pani Dzikiej Zwierzyny.

Jak w poprzedniej baśni, tak i tutaj władający magią antagonista łatwo wpada w gniew. Widząc, że przez zwierzęcych pomocników nic nie zdziałał, sam przychodzi na wesele, okazując przy tym zupełną pogardę dla obyczajów obowiązują-

${ }^{69}$ J.B. Russell, op. cit., s. 23. Zob. też E.E. Evans-Pritchard, Czary, wyrocznie i magia u Azande, przeł. S. Szymański, wstęp J. Tokarska-Bakir, Warszawa 2008, s. 23, 37, 202-203. 
cych w społeczności ludzkiej oraz dla religii ${ }^{70}$. Ostatecznie nie spotyka go jednak śmierć, jak zwykle dzieje się z bohaterami tego rodzaju, lecz tylko utrata wzroku. To jednak wystarcza, żeby tyran „wyrzekł się mędrkowania swojego, napędzania ludziom strachu" ${ }^{\prime 11}$. Ten element fabuły uwydatnia, charakterystyczną też dla baśni zachodnich, podrzędność męskiej mocy magicznej wobec tej kobiecej — zarówno bowiem w Grimmowskich opowieściach o wiedźmach, jak i w rosyjskich wyobrażeniach Baby Jagi słabość czy nawet całkowity brak zmysłu wzroku nie zmniejszały ich potęgi i lęku, jaki budziły wśród ludzi.

Postaciami władającymi magią — lub też magicznymi z samej swej natury — pośrednimi między czarownikami a magicznymi zwierzętami są w rosyjskich baśniach smoki. Należy tu o nich wspomnieć, ponieważ w każdym tekście mówi się o nich jako o istotach płci męskiej. O tym, że według niektórych źródeł tego rodzaju stworzeniem jest Kościej Nieśmiertelny, była już mowa ${ }^{72}$. Swoiste odzwierciedlenie motywu wielowarstwowego ukrycia śmierci tej postaci można znaleźć w baśni 162 (53): w ciele trzeciego z występujących tam smoków, dwunastogłowego, pod czterema innymi „warstwami” (kufra, zająca, kaczki i jajka), schowane zostało nasionko, które - podpalone - pozwala roztopić kryształową górę i uwolnić uwięzioną w niej królewnę. Baśniowe smoki moją status pośredni, wykazują cechy zarówno ludzi, jak i zwierząt. Bardzo charakterystyczne (wedle zbioru przygotowanego przez Łużnego — nawet bardziej niż dla Bab Jag) jest dla nich węszenie i wyczuwanie zapachu nie tylko ludzkiego, lecz także specyficznego etnicznie: ruskiego (tak dzieje się w baśni 131 [39] i 140 [40]). O ile Baby Jagi mieszkały według niektórych baśni pod ziemią, o tyle smoki wydają się powiązane z żywiołem wody: to z niej się wyłaniają, a niekiedy bywają nawet synami „morskiego cara” (baśń $125[37])^{73}$. O pokrewieństwie zaś ontologicznym wobec gatunku ludzkiego ${ }^{74}$ świadczy to, że potrafią przyjmować postać młodzieńców, a nawet uwodzić kobiety — jak smok Gorynycz z omawianej już baśni 204 (62) lub ten z baśni nr 359 (116), który przylatuje do córki kupca i zabija jej kolejnych mężów.

$\mathrm{W}$ mitologii słowiańskiej postać smoka, kojarzona z chtonicznym bogiem Welesem, podobnie jak w baśniach ma mroczne oblicze - „[j]est to postać archaiczna, wywodząca się od [praindoeuropejskiego] potwora chaosu, ucieleśnie-

${ }^{70}$ Zob. Rosyjskie bajki ludowe..., s. 386.

71 Ibidem, s. 387.

72 O powiązaniu tych postaci może świadczyć też to, że w wielu baśniach smok, podobnie jak Kościej, odgrywa rolę porywacza, co łączy się z pradawnym postrzeganiem śmierci jako efektu uprowadzenia duszy — lub jednej z dusz - człowieka. Zob. W. Propp, op. cit., s. 239-240, 274.

${ }^{73}$ Rosyjskie bajki ludowe..., s. 103. Podziemna lokalizacja zaświatów niekoniecznie musi oznaczać ich odrębność od sfery akwatycznej. Według niektórych rekonstrukcji mitologii słowiańskiej Weles, władca krainy umarłych, mieszka „pośrodku podziemnego morza” (A. Szyjewski, op. cit., s. 79). Na temat powiązanych z wodną naturą smoka mitologicznych wyobrażeń z różnych części świata zob. W. Propp, op. cit., s. 280-286.

${ }^{74}$ Motyw tego pokrewieństwa wykorzystała Ursula K. Le Guin w cyklu o Ziemiomorzu. 
nia destrukcyjnych mocy rozkładających ład kosmiczny"75. Bohater pokonujący smoka przywraca więc nie tylko porządek codzienny, lecz także homeostazę w wymiarze uniwersalnym. Skoro istota tego rodzaju jednoznacznie kojarzy się ze światem podziemnym, chaosem i złem, nie dziwi, że w baśni 305 (88) Król Smok to niemal dokładny odpowiednik diabła z Grimmowskiej baśni $29^{76}$.

\section{Podsumowanie}

O jednoznacznie negatywnym postrzeganiu postaci baśniowych wiedźm i czarowników, a także o antypsychologizmie oraz jednowymiarowości moralnej i etycznej cechujących przedstawienia tych postaci była już mowa ${ }^{77}$. Dodać do tego można jeszcze tezę o ich amoralności, czyli istnieniu poza wszelkimi zasadami etyki. Wspomniano już również, iż o takim statusie decyduje „chroniczny” kontakt z magią — odmienny od tego, w jaki wchodzą z nią zwykli ludzie korzystający z czarodziejskich przedmiotów lub z pomocy niezwykłych zwierzą ${ }^{78}$.

Niewiadomy jest natomiast status mądrych niewiast — jedynego w Grimmowskich baśniach wyjątku od reguły, że stałe paranie się magią powoduje internalizację zła. Nie wyjaśnia się, skąd pochodzi moc takich kobiet i jaki ma zakres. W każdym razie $\mathrm{w}$ baśniowych narracjach prezentowane one są jako znacznie potężniejsze niż wiejskie znachorki, przeciwstawiane ludowym wyobrażeniom o wiedźmach ${ }^{79}$. W wypadku Śpiącej królewny Grimmowie wprowadzili mądre niewiasty w miejsce wróżek, ale czy było tak też w kwestii innych tekstów ze zbioru, w których takie bohaterki się pojawiają? Trudno orzec, pozostaje więc stwierdzić, iż „mądre” wydają się najbardziej tajemniczymi z baśniowych postaci władających magią — zwłaszcza że, w przeciwieństwie do wiedźm/czarownic, nie mają swojego męskiego odpowiednika. W interpretacjach feministycznych kobiece bohaterki posługujące się czarami - również te przedstawiane w baśniach jako jednoznacznie złe - są traktowane jako relikt dawnych czasów matriarchatu, kiedy nadrzędną rolę odgrywała żeńska zasada świata, uosabiana przez Wielką Boginię. Jedną z trzech jej postaci była Starucha i z tym właśnie wiąże się przypisywanie wiekowym kobietom mocy, potęgi i, po prostu, władzy, w kulturach tradycyjnych przynależnej raczej mężczyznom $^{80}$. Jeśli podążać tym tropem, wydaje się, że właśnie obrazy mądrych niewiast

75 A. Szyjewski, op. cit., s. 57.

76 Więcej na temat baśniowych smoków zob. na przykład A. Mianecki, Przekleństwo królów, plaga królestw — smok w wybranych opowieściach polskiego folkloru tradycyjnego, [w:] Powodzie, plagi, życie i inne katastrofy, red. K. Konarska, Wrocław 2012.

77 Zob. D. Ucherek, op. cit., s. 11-12.

78 Zob. ibidem, s. 12.

79 Zob. B. Baranowski, op. cit., s. 239-240.

${ }^{80}$ Zob. G. Lasoń-Kochańska, Dziewczynka, macocha, czarownica..., s. 24, 23: „Umiejętność metamorfozy, panowania nad materią i żywiołami oraz powiązanie ze światem zwierząt wskazują, że czarownica posiada szczególną, jak na starą kobietę, władzę. Strach przed baśniową czy rzekomą czarownicą zawsze był uznaniem jej mocy”; ,[z baśni] wyłania się obraz czarownicy jako kobiety związanej z pierwotnymi, dzikimi i groźnymi siłami przyrody oraz [...] »z natury swej« szkodzącej 
są najpełniejszym odzwierciedleniem owego dawnego, prepatriarchalnego okresu, zwłaszcza zaś samej Bogini. Mają bowiem moc i wolność czarownic, a zarazem nie muszą zmagać się z ludzką pogardą i prześladowaniami, lecz (o ile nie myli się ich $\mathrm{z}$ wiedźmami) są darzone szacunkiem.

Wśród zgromadzonych przez Afanasjewa baśni rosyjskich (w reprezentatywnym wyborze Łużnego) nie znajdziemy kobiecych postaci władających magią w pełni analogicznych do Grimmowskich „mądrych niewiast”. Wydaje się wszak, że wyobrażeniem im najbliższym jest bohaterka najbardziej charakterystyczna dla tej kategorii: Baba Jaga — jeśli w danej baśni ukazuje oblicze donatorki i testerki, a nie porywaczki dzieci lub brutalnej antagonistki, wojującej z postaciami waloryzowanymi pozytywnie. W rosyjskich baśniach magicznych zarówno zwykłe wiedźmy, jak i czarownicy przedstawiani są tak jak w wariantach zachodnich, ale tym, co wyróżnia wschodniosłowiański zbiór i stanowi o jego specyfice, jest właśnie wyobrażenie wielopostaciowej i wieloznacznej Baby Jagi: zarazem bogini, czarownicy, demona, a nawet... nieboszczyka. Również ukazywanie umarłych władających magią — po tym jak powrócili oni w postaci upiorów — odróżnia drugi z przeanalizowanych zbiorów od pierwszego. W opowieściach rosyjskich wyjątkowo wyraźnie zarysowuje się powiązanie motywu parania się czarami z egzystencją nie tylko nieludzką, ale też labilną w inny sposób: polegający na swoistym trwaniu w sferze pośredniej między życiem a śmiercią.

Prawidłowość ta występuje też w wypadku najbardziej charakterystycznego spośród wschodniosłowiańskich bohaterów męskich władających magią: Kościeja Nieśmiertelnego. Postać owa, zawsze odgrywająca rolę antagonisty, wyróżnia się poziomem swojej mocy, zdecydowanie górującej nad możliwościami jakichkolwiek innych czarowników, czy to Afanasjewowskich, czy Grimmowskich. Ponadto wykazuje hybrydalność jeszcze innego rodzaju — z jednej strony jest męskim odpowiednikiem Baby Jagi, z drugiej zaś wiąże się z wyobrażeniem smoka. Trzeba też zwrócić uwagę, że ta ostatnia istota, również władająca magią, pojawia się w baśniach rosyjskich znacznie częściej niż w niemieckich, co łączyć można ze słowiańską wizją zaświatów, opartą na opozycji węża/smoka i ptaka ${ }^{81}$.

Jedną z najbardziej charakterystycznych cech wszystkich baśni jest występowanie w obrębie ich świata przedstawionego dwóch sfer: realistycznej i fantastycznej. Chatka Baby Jagi - czy nawet zwykłej czarownicy — tworzy zawsze granicę między tymi sferami, a sama owa tajemnicza istota jest owej granicy strażniczką. Docierając do tego obszaru, bohater musi nie tylko zmierzyć się ze złem zewnętrznym, lecz także skonfrontować się ze słabościami własnej psychiki. Przywracając równowagę $\mathrm{w}$ świecie, wkracza jednocześnie na wyższy poziom osobistego rozwoju. Baśniowe postacie władające magią — niezależnie czy grają

ludziom. Gdy jednak podąża się pod prąd tych negatywów, wiele dobrego można z nich wyczytać. Przede wszystkim baśniowa czarownica jest — mimo swej starości — istotą potężną i posiadającą władzę. Pochodzi nie z tego świata, jej tożsamość jest niepotwierdzona".

${ }^{81}$ Stąd między innymi opozycja Wyraju ptasiego i Wyraju wężowego. Ptak jest istotą uraniczną, wąż/smok zaś - chtoniczną. Zob. A. Szyjewski, op. cit., s. 53, 73, 77-78, 192-193, 200-201. 
rolę antagonistów, czy też pomocników, donatorów lub tych, którzy inicjują rozmaite próby, jakie bohater musi przejść — zawsze okazują się katalizatorami tych pozytywnych procesów.

\section{Bibliografia}

Aarne A., Verzeichnis der Märchentypen, Helsinki 1910.

Baranowski B., W kręgu upiorów i wilkołaków, Łódź 1981.

Cart M., From Insider to Outsider: The Evolution of Young Adult Literature, „Voices from the Middle” $2001, \mathrm{nr} 2$.

Cirlot J.E., Stownik symboli, przeł. I. Kania, Kraków 2012.

Cooper J.C., Zwierzęta symboliczne i mityczne, przeł. A. Kozłowska-Ryś, L. Ryś, Poznań 1998.

Czeremski M., Baba Jaga i królewny. Postać kobiety w bajce magicznej, [w:] Kobiety i religie, red. K. Leszczyńska, A. Kościańska, Kraków 2006.

Dixon-Kennedy M., Encyclopedia of Russian and Slavic Myth and Legend, Santa Barbara 1998.

Doroszewski W., Moździerz, [hasło w:] idem, http://sjp.pwn.pl/doroszewski/mozdzierz;5453222. html [dostęp: 9.01.2017].

Doroszewski W., Stępa, [hasło w:] idem, Wielki słownik języka polskiego, http://sjp.pwn.pl/doroszewski/stepa;5501106.html [dostęp: 9.01.2017].

Engelking A., Klatwa. Rzecz o ludowej magii stowa, Warszawa 2010.

Estés C.P., Biegnaca z wilkami, przeł. A. Cioch, Poznań 2001.

Evans-Pritchard E.E., Czary, wyrocznie i magia u Azande, przeł. S. Szymański, wstęp J. Tokarska-Bakir, Warszawa 2008.

Forrester S., Introduction: Baba Yaga: The Wild Witch of the East, [w:] Baba Yaga: The Wild Witch of the East in Russian Fairy Tales, wstęp i przekł. S. Forrester, Jackson, MS, 2013.

Frazer J.G., Złota gałaź. Studia z magii i religii, przeł. H. Krzeczkowski, Kraków 2012.

Gasparini E., Il Matriarcato slavo. Antropologia culturale dei protoslavi, Firenze 1973.

Gieysztor A., Mitologia Słowian, wstęp K. Modzelewski, posł. L. Słupecki, oprac. na podst. rkpsu A. Pieniądz, wyd. 3, zmien., rozszerz., Warszawa 2006.

Graves R., Mity greckie, przeł. H. Krzeczkowski, Kraków 2009.

Grimm W. i J., Baśnie dla dzieci i dla domu, il. O. Ubbelohde, przeł. E. Pieciul-Karmińska, Poznań 2010, t. 1-2.

Johns A., Baba Yaga: The Ambiguous Mother and Witch of the Russian Folktale, New York 2006.

Kopaliński W., Stownik symboli, Warszawa 2006.

Krzak Z., Od matriarchatu do patriarchatu, Warszawa 2007.

Krzyżanowski J., Polska bajka ludowa w układzie systematycznym, wyd. 2, rozszerz., Wrocław 1962, t. 1.

Lasoń-Kochańska G., Dziewczynka, macocha, czarownica. Obraz kobiety w baśni, „Literatura Ludowa" 2011, nr 4/5.

Lasoń-Kochańska G., Odbaśnianie czarownicy. Kobieca starość wobec tradycji kultury, [w:] Dojrzewanie do petni życia. Starość w literaturze polskiej i obcej, red. S. Kruk, E. Flis-Czerniak, Lublin 2006.

Łużny R., Aleksander Afanasjew i jego „Rosyjskie bajki ludowe”, [w:] Rosyjskie bajki ludowe ze zbioru Aleksandra Afanasjewa, oprac., wstęp, przypisy R. Łużny, wyb., przygot. do druku H. Kowalska, Kraków 2001.

Mianecki A., Jajo w wybranych watkach ludowych bajek magicznych, [w:] Mit, prawda, imaginacja, red. P. Kowalski, Wrocław 2011.

Mianecki A., Przekleństwo królów, plaga królestw - smok w wybranych opowieściach polskiego folkloru tradycyjnego, [w:] Powodzie, plagi, życie i inne katastrofy, red. K. Konarska, Wrocław 2012. 
Moszyński L., Dlaczego naukowe opisy prastowiańskich wierzeń są tak różnorodne, „Studia Mythologica Slavica" 1998, nr 1.

Neumann E., Die grosse Mutter. Der Archetyp des grossen Weiblichen, Zürich 1956.

Propp W., Historyczne korzenie bajki magicznej, przeł. J. Chmielewski, Warszawa 2003.

Rosyjskie bajki ludowe ze zbioru Aleksandra Afanasjewa, oprac., wstęp, przypisy R. Łużny, wyb., przygot. do druku H. Kowalska, Kraków 2001.

Russell J.B., Krótka historia czarownictwa, przeł. J. Rybski, Wrocław 2003.

Rutkowski P., Kot czarownicy. Demon osobisty w Anglii wczesnonowożytnej, Kraków 2012.

Rzepnikowska I., Rosyjska i polska bajka magiczna (AT 480) w kontekście kultury ludowej, Toruń 2005.

Stomma L., Antropologia kultury wsi polskiej XIX w., Warszawa 1986.

Szrejter A., Demonologia germańska. Duchy, demony i czarownice, Gdańsk 2011.

Szyjewski A., Religia Stowian, Kraków 2003.

Thompson S., The Types of the Folk-Tale. A Classification and Bibliography, Helsinki 1961.

Ucherek D., Sposoby funkcjonowania postaci czarownic i czarowników oraz magicznych przedmiotów w baśniach braci Grimmów, „Literatura Ludowa” 2015, nr 4/5.

Urbańczyk S., Dawni Stowianie. Wiara i kult, Wrocław 1991.

Uther H.-J., The Types of International Folktales: A Classification and Bibliography, Based on the System of Antti Aarne and Stith Thompson, Helsinki 2004.

Wróblewska V., „, Od potworów do znaków pustych”. Ludowe demony w polskiej literaturze dla dzieci, Torun 2014.

Zipes J., Unfathomable Baba Yagas, [w:] Baba Yaga: The Wild Witch of the East in Russian Fairy Tales, wstęp i przekł. S. Forrester, Jackson, MS, 2013.

\section{Baba Yaga, Koschei the Immortal and other magic-wielding characters in Russian magic fairy tales compared to witches and sorcerers from the Brothers Grimm fairy tales}

\section{Summary}

The article is an analysis of the images of magic-wielding characters in Russian magic fairy tales. The basis of this analysis is a set of fairy tales collected by Alexander Afanasyev. The author focuses primarily on the characters of Baba Yaga and Koschei the Immortal, pointing in particular to the ambiguity of the former. She can be seen as a witch, a demon and deity, as an antagonist — just like other fairy tale witches - but also as a donor, tester, and catalyst of the protagonist's evolution. In the case of Koschei, although he always turns out to be an antagonist, what deserves attention is the level of his power - much higher than in the case of "lower-order" sorcerers - and the motif of the seven-stage soul hiding as the source of immortality. Also considered is the image of dragons, characteristic of Slavic fairy tales - perceived in this cultural circle as chthonic beings, related to snakes and in opposition to birds, i.e. uranic beings. In the course of the analysis, the author also compares the images of magic-wielding characters in Afanasyev's collection with those gathered by the Brothers Grimm.

Keywords: fairy tale, literary figure, magic, witch, sorcerer, Baba Yaga, Koschei the Immortal 